\title{
Peronospora sparsa on Cultivated Rubus arcticus and Its Detection by PCR Based on ITS Sequences
}

\author{
Hannele Lindqvist, Institute of Biotechnology, University of Helsinki, and Department of Plant Biology, Genetic \\ Centre, Swedish University of Agricultural Sciences (SLU); Hilkka Koponen, Department of Plant Biology, Plant \\ Pathology Section, P.O. Box 28, FIN-00014 University of Helsinki, Finland; and Jari P. T. Valkonen, Institute of \\ Biotechnology, University of Helsinki, Finland, and Department of Plant Biology, Genetic Centre, Swedish Univer- \\ sity of Agricultural Sciences (SLU), Box 7080, S-750 07 Uppsala, Sweden
}

\begin{abstract}
Lindqvist, H., Koponen, H., and Valkonen, J. P. T. 1998. Peronospora sparsa on cultivated Rubus arcticus and its detection by PCR based on ITS sequences. Plant Dis. 82:1304-1311.

In 1994 to 1996, large yield losses were reported in cultivated arctic bramble (Rubus arcticus) due to berries drying in the middle of the growing season in the entire cultivation area $\left(62^{\circ}\right.$ to $66^{\circ} \mathrm{N}$ ) in Finland. Interveinal, angular, purple-red lesions on leaves are associated with the dryberry disease. Cultivations of arctic bramble were inspected in 1995 and 1996, and 69 plant samples and 137 rootstocks were collected and examined for fungi in the laboratory. Peronospora sparsa was the species most commonly found in all types of samples tested, but Fusarium avenaceum, Cylindrocarpon destructans, and Botrytis cinerea also were detected. P. sparsa was shown to overwinter in the underground parts of arctic bramble. Laboratory tests showed that the two main cultivars of arctic bramble (Pima and Mespi) were susceptible to $P$. sparsa. Sequences of the internal transcribed spacer (ITS) regions 1 and 2 of the rDNA genes were determined in four and six isolates, respectively, of $P$. sparsa, and little sequence variability was detected. The corresponding ITS regions of arctic bramble, the above mentioned fungi, a Phoma sp. previously isolated from arctic bramble, and Phytophthora cactorum isolated from strawberry were also determined and compared with the corresponding sequences of $P$. sparsa. Subsequently, two pairs of primers were designed to the ITS regions that could be used to detect either P. sparsa and Phytophthora cactorum, or only P. sparsa, respectively, by polymerase chain reaction (PCR) using two different types of thermal cyclers ("heated block" Mini Cycler and "hot air flow" Rapid Cycler).
\end{abstract}

Arctic bramble (Rubus arcticus L.; Rosaceae), also called arctic raspberry or nectaberry, is a perennial species. Berries are highly valued for their fine and strong aroma and are mainly used in the liqueur industry. $R$. arcticus is native to subarctic Eurasia but produces significant yields only between 62 and 66 degrees of latitude $(10,20)$. It is commercially cultivated only in Finland, and production is mainly based on two selected, vegetatively propagated clones, cvs. Pima and Mespi. However, due to self sterility, production of berries requires the two cultivars to be grown together $(20,21)$.

Since 1994, farmers have reported serious yield losses due to berries drying in the middle of the growing season. The yield loss is often $50 \%$, but in some cases no yield is obtained. The plants with drying berries also have interveinal, angular, purple-red lesions on leaves (Fig. 1). Similar symptoms have been reported elsewhere

Corresponding author: J. P. T. Valkonen

E-mail: jari.valkonen@vbiol.slu.se

Accepted for publication 22 August 1998.

Publication no. D-1998-1014-01R

(C) 1998 The American Phytopathological Society on many Rubus spp. that are affected by downy mildew caused by Peronospora sparsa Berkeley (syn. P. rubi Rabenshorst) $(1,4,7,12,23,27)$. In boysenberry, $P$. sparsa overwinters in belowground parts and grows systemically to the emerging shoots in the next growing season (24). In the previous study by Ruokola (19), P. sparsa was not found in cultivated arctic bramble; whereas Cylindrocarpon destructans, $\mathrm{Fu}$ sarium avenaceum, and Botrytis cinerea were reported to occur and be pathogenic or weakly pathogenic.

The aim of this study was to identify fungi in cultivated arctic bramble affected by the symptoms described above. In further investigations, special emphasis was put on $P$. sparsa because it was found to be common and pathogenic in arctic bramble. A specific detection method based on polymerase chain reaction (PCR) was developed for identification of $P$. sparsa, and the reaction conditions were optimized for two different types of thermal cyclers.

\section{MATERIALS AND METHODS}

Identification of fungi in samples collected from the field. Whole plants with poor growth and/or dry unripe berries were collected from four sites in western Finland in the beginning of August 1995
(Table 1, Fig. 2). Roots, leaves, and flower stalks were excised, incubated on water agar in petri dishes at room temperature under natural daylight, and examined for fungi under a microscope after 14 days. Several fungi could be readily identified on plant samples, but they were also transferred to potato dextrose agar (PDA; Difco Laboratories, Detroit, MI) and grown at room temperature to confirm the identification (2,3). In October, 27 rootstocks were collected from one cultivation site where the dryberry disease had been very severe in the summer. After 3 months of storage at $5^{\circ} \mathrm{C}$, soil and all aboveground parts were removed, and roots were replanted in a steam-sterilized mixture of washed sand and peat $(5: 1)$ in pots and placed in a growth chamber $\left(17^{\circ} \mathrm{C}\right.$, photoperiod $12 \mathrm{~h}$ ). As sprouts emerged, each pot was covered with a plastic bag. Plants were examined for fungi several times over 3 months. Identification of fungi was done under microscope, and in many cases, isolation to and culture on PDA was carried out to confirm identification $(2,3)$.

In 1996, many cultivations of arctic bramble in western and eastern parts of Finland were visited and inspected in June and the beginning of July (Table 1, Fig. 2). Leaf samples were collected from plants with foliar symptoms such as purple lesions (Fig. 1), placed on water agar in petri dishes, and incubated in a growth chamber at $17^{\circ} \mathrm{C}$ and a $12-\mathrm{h}$ photoperiod. Fungi were identified as described above. Rootstocks were collected by farmers during October to December and sent for inspection (Table 1, Fig. 2). Rootstocks were stored at $4{ }^{\circ} \mathrm{C}$ for 1 month and then grown as described above, except that a mixture of peat and vermiculite (4:1) and a photoperiod of $16 \mathrm{~h}$ were used.

Healthy plant material and pure cultures of fungi. In vitro propagated healthy plantlets of arctic bramble cvs. Pima and Mespi were obtained from the Healthy Plant Unit, Agricultural Research Centre, Laukaa, Finland.

A single sporangiophore of $P$. sparsa was picked up with forceps from an infected specimen of arctic bramble under dissection microscope and placed on a drop of sterile water on the lower side of a leaf excised from a tissue-culture-propagated, 
healthy plantlet of arctic bramble cv. Pima. The inoculated leaf was placed on water agar in a petri dish, and the dish was sealed with a slip of Parafilm and incubated in a growth chamber under the conditions described above. Mycelia and sporangiophores (Fig. 3) were visible on the inoculated spot of the leaf after 7 days and were used for DNA isolation. Some leaves were stored at $-80^{\circ} \mathrm{C}$. After storage, infectious sporangia were released by soaking the frozen leaves in sterile water and used for inoculation of new leaves.

One isolate each of $F$. avenaceum, $C$. destructans, and $B$. cinerea isolated from arctic bramble in this study (Table 2) were grown on PDA as pure cultures at room temperature. An isolate of Phoma sp. previously isolated from arctic bramble (19) and two isolates of Phytophthora cactorum isolated from strawberry (Fragaria $\times$ ananassa) (provided by Päivi Parikka, Agricultural Research Centre, Jokioinen) were also grown on PDA.

DNA isolation. Mycelia and sporangia of $P$. sparsa were collected from the detached leaves 2 weeks after inoculation, either with forceps under preparation microscope, or sporangia were washed from leaves with sterile water to a microfuge tube and pelleted by centrifugation. Sporangia and mycelia were ground in the microfuge tube with a pestle using sand or Carborundum. Subsequently, DNA isolation was carried out using a method provided by J. Hantula, Finnish Forest Research Institute, Vantaa. Lysis buffer $(50$ $\mathrm{mM}$ Tris-HCl, $\mathrm{pH}$ 7.2; 50 mM EDTA, $\mathrm{pH}$
8.0; $3 \%$ sodium dodecyl sulfate (SDS); $1 \%$ $\beta$-mercaptoethanol) was added, and samples were incubated at $65^{\circ} \mathrm{C}$ for $1 \mathrm{~h}$. The mixture was treated with phenol:chloro- form (1:1) saturated with Tris-EDTA (Sigma Chemical Co., St. Louis, MO), vortexed for $3 \mathrm{~min}$, and centrifuged at full speed (14 $000 \mathrm{rpm})$ in a microfuge

Table 1. Occurrence of fungi in cultivated Rubus arcticus sampled at different sites in Finland in 1995 and 1996

\begin{tabular}{|c|c|c|c|c|c|c|}
\hline \multirow[b]{2}{*}{$\begin{array}{l}\text { Year } \\
\text { Site }\end{array}$} & \multirow[b]{2}{*}{ Time } & \multirow[b]{2}{*}{ Sample type } & \multicolumn{3}{|c|}{ Samples containing fungi } & \multirow[b]{2}{*}{ Total } \\
\hline & & & $\begin{array}{c}\text { Peronospora } \\
\text { sparsa }\end{array}$ & $\begin{array}{l}P \text {. sparsa, } \\
\text { other fungi }\end{array}$ & $\begin{array}{l}\text { Other } \\
\text { fungi }\end{array}$ & \\
\hline \multicolumn{7}{|l|}{1995} \\
\hline Alahärmä & August 1 & Whole plant & 0 & 5 & 3 & 8 \\
\hline Alajärvi & August 1 & Whole plant & 0 & 4 & 4 & 8 \\
\hline Himanka & August 1 & Whole plant & 0 & 4 & 2 & 6 \\
\hline Vimpeli & August 1 & Whole plant & 0 & 1 & 3 & 4 \\
\hline Haapamäki & October 14 & Rootstock & 0 & 18 & 0 & 27 \\
\hline \multicolumn{7}{|l|}{1996} \\
\hline Alahärmä & June 4 & Leaves & 0 & 1 & 0 & 1 \\
\hline Alajärvi & June 4 & Leaves & 0 & 1 & 0 & 1 \\
\hline Himanka & June 4 & Leaves & 0 & 1 & 0 & 1 \\
\hline Juankoski & July 3 & Leaves & 2 & 0 & 0 & 2 \\
\hline Karttula & July 3 & Leaves & 1 & 4 & 2 & 7 \\
\hline Lumijoki & July 10 & Leaves & 5 & 12 & 1 & 18 \\
\hline Muuruvesi & July 3 & Leaves & 3 & 2 & 0 & 5 \\
\hline Vimpeli & June 4 & Leaves & 3 & 3 & 2 & 8 \\
\hline Alajärvi & Oct-Dec ${ }^{\mathrm{a}}$ & Rootstocks & $* \mathrm{~b}$ & 6 & 1 & 21 \\
\hline Haapamäki & Oct-Dec & Rootstocks & $*$ & 3 & 3 & 24 \\
\hline Himanka & Oct-Dec & Rootstocks & $*$ & 7 & 0 & 9 \\
\hline Kempele & Oct-Dec & Rootstocks & $*$ & 0 & 3 & 5 \\
\hline Lumijoki & Oct-Dec & Rootstocks & $*$ & 8 & 0 & 14 \\
\hline Muhos & Oct-Dec & Rootstocks & $*$ & 0 & 2 & 6 \\
\hline Muuruvesi & Oct-Dec & Rootstocks & $*$ & 4 & 0 & 8 \\
\hline Pihtipudas & Oct-Dec & Rootstocks & $*$ & 1 & 6 & 11 \\
\hline Säyneinen & Oct-Dec & Rootstocks & $*$ & 2 & 1 & 5 \\
\hline Vimpeli & Oct-Dec & Rootstocks & $*$ & 1 & 1 & 7 \\
\hline
\end{tabular}

${ }^{a}$ Rootstocks were collected by farmers during October to December.

b Many plants grown from the rootstocks examined in 1996 may have contained only $P$. sparsa, but because plants were not grown long enough to confirm this, all plants that contained $P$. sparsa are indicated in the next column.

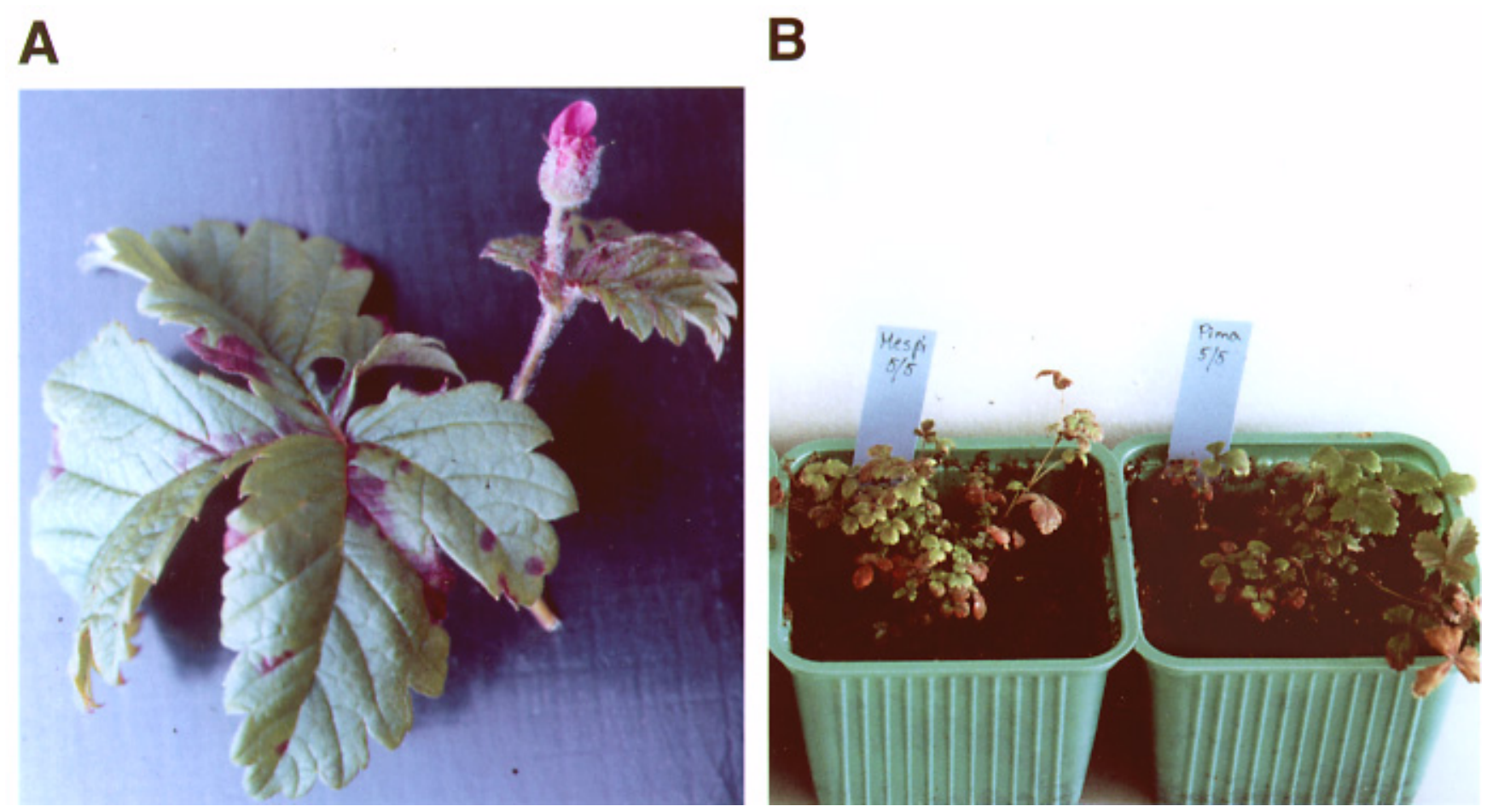

Fig. 1. (A) Arctic bramble infected with Peronospora sparsa in the field. Leaves show characteristic purple lesions. Mycelia, sporangiophores, and sporangia of $P$. sparsa are visible on the flower stalk, flower bud, and top leaves next to the flower bud. (B) Purple leaves, yellowing, and poor growth of arctic bramble cvs. Mespi and Pima 11 weeks after inoculation with $P$. sparsa in a growth chamber. 
(Biofuge Pico, Heraeus Instruments, Hanau, Germany) for $5 \mathrm{~min}$. The top layer was transferred to a new tube, treated with chloroform:isoamylalcohol (24:1), vortexed, and centrifuged as previously. DNA was precipitated with a PEG solution (2.5 $\mathrm{M} \mathrm{NaCl}, 20 \%$ polyethylene glycol 6000 ) on ice for $1 \mathrm{~h}$ and pelleted by centrifugation at $14,000 \mathrm{rpm}\left(4^{\circ} \mathrm{C}\right)$ for $20 \mathrm{~min}$. DNA pellets were washed with $70 \%$ ethanol, dissolved in 25 to $50 \mu \mathrm{l}$ of sterile distilled water, and stored at $-20^{\circ} \mathrm{C}$.

Mycelia of the other fungi mentioned above were collected from the top of the

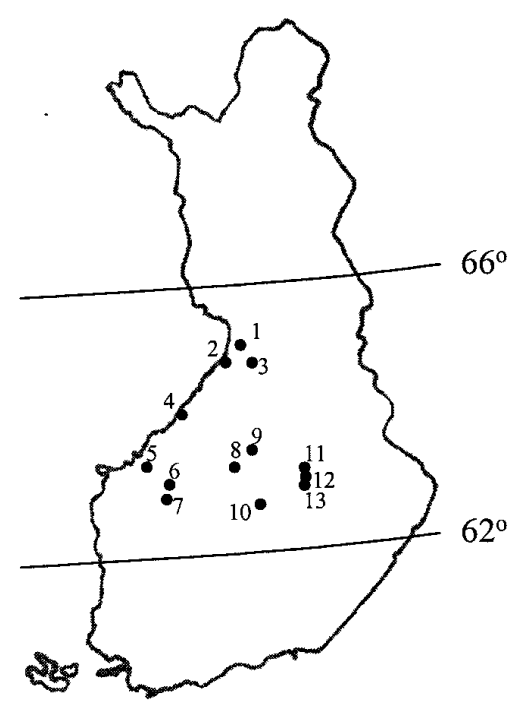

Fig. 2. Sampling sites in Finland of the cultivation of arctic bramble examined for Peronospora sparsa in this study: 1 , Kempele; 2 , Lumijoki; 3, Muhos; 4, Himanka; 5, Alahärmä; 6, Vimpeli; 7, Alajärvi; 8, Pihtipudas; 9, Haapamäki; 10, Karttula; 11, Säyneinen; 12, Juankoski; 13, Muuruvesi.

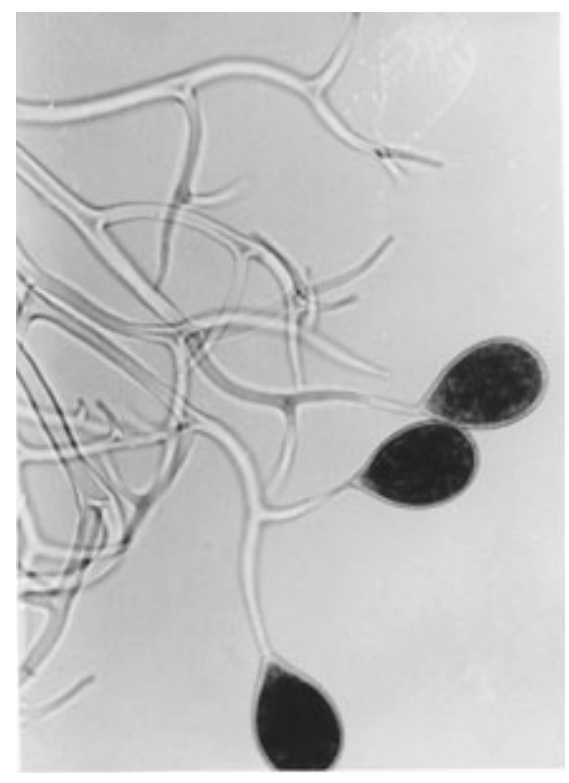

Fig. 3. Sporangiophores and sporangia of Peronospora sparsa grown on arctic bramble $(\times 500)$. agar after 2 to 4 weeks of growth on PDA and ground to a fine powder in liquid nitrogen using a mortar and a pestle. DNA was isolated as described above.

DNA was isolated from micropropagated arctic bramble as described by Porebski et al. (17). DNA isolation from the plants collected from the field was carried out as described by Graham et al. (6), except that the extraction buffer of Porebski et al. (17) was used.

Amplification and sequencing of ITS regions. The internal transcribed spacer (ITS) regions 1 and 2 were amplified using the previously described universal primers (Table 3) targeted to conserved regions in the 18S, 5.8S, and 28S rRNA genes (28). PCR reaction mix for amplification of ITS1 and ITS2 sequences contained 0.1 mM dNTPs, $0.25 \mu \mathrm{M}$ primers, $1 \mathrm{U}$ Dynazyme TM II DNA polymerase (Finnzymes OY), 1× Dynazyme PCR buffer with 1.5 $\mathrm{mM} \mathrm{MgCl}_{2}$, and 1 to $50 \mathrm{ng}$ of template DNA. Sterile distilled water was added to reach the final volume of $50 \mu \mathrm{l}$. PCR amplification was carried out with a thermal cycler (PTC-150 Mini Cycler with Hotbonnet, MJ Research, Massachusetts) using the following program: $1 \mathrm{~min}$ at $94^{\circ} \mathrm{C}$ for initial denaturation followed by 30 cycles consisting of $40 \mathrm{~s}$ of denaturation at $92^{\circ} \mathrm{C}, 2 \mathrm{~min}$ of annealing at $50^{\circ} \mathrm{C}$, and 3 min of DNA synthesis at $75^{\circ} \mathrm{C}$. An extension time of $10 \mathrm{~min}$ at $74^{\circ} \mathrm{C}$ was added at the end of the last cycle. Sequence of the amplified product was determined by direct sequencing using the solid phase method (18), and sequencing reactions were analyzed using an automated sequencer (ALFexpress, Pharmacia, Uppsala, Sweden) at the Institute of Biotechnology, University of Helsinki. Sequence alignments were made using the Biology Work Bench NCSA ClustalW program $(9,25)$.

Optimization of PCR conditions. In plant pathology laboratories, the PCR cycler most commonly in use is the conventional model with a heated block, often also provided with a hot lid to decrease evaporation from the reaction mix amplified in a microfuge tube. Thirty cycles of amplification take approximately $2 \mathrm{~h}$, and usually the maximum of 96 samples can be amplified simultaneously. Rapid Cycler (Idaho Technologies, Idaho Falls) represents another type of thermal cycler in which reaction mix is transferred to a glass capillary for amplification, and thermal cycles are created by a flow of hot and cool air (29,30). Thirty cycles of amplification take approximately $15 \mathrm{~min}$, and 48 samples can be amplified simultaneously.

PCR conditions were established for the specific and reproducible detection of $P$. sparsa using the two above mentioned types of thermal cyclers: a heated block cycler with a hot lid (PTC-150 Mini Cycler with Hotbonnet), and Rapid Cycler. The variables tested included primer $(0.25$ or $0.50 \mu \mathrm{M})$, dNTP $(0.1$ or $0.2 \mathrm{mM})$, and

Table 2. The fungal isolates examined in this study

\begin{tabular}{|c|c|c|c|c|c|}
\hline \multirow[b]{2}{*}{ Species } & \multirow[b]{2}{*}{ Isolate } & \multirow[b]{2}{*}{ Host } & \multirow{2}{*}{$\begin{array}{c}\text { Sampling } \\
\text { site }\end{array}$} & \multicolumn{2}{|c|}{ EMBL accession no. } \\
\hline & & & & ITS1 & ITS2 \\
\hline Peronospora sparsa & 150 & Rubus arcticus & Lumijoki & $\mathrm{ND}^{\mathrm{a}}$ & Y15822 \\
\hline P. sparsa & $62 \mathrm{a} 1$ & $R$. arcticus & Haapamäki & $\mathrm{Y} 15815^{\mathrm{b}}$ & Y15820 \\
\hline P. sparsa & $62 \mathrm{a} 3$ & R. arcticus & Haapamäki & $Y 15815^{b}$ & Y15819 \\
\hline P. sparsa & 69 & R. arcticus & Haapamäki & ND & Y15817 \\
\hline P. sparsa & 71 & R. arcticus & Alajärvi & $Y 15815^{b}$ & Y15823 \\
\hline P. sparsa & 74 & $R$. arcticus & Vimpeli & Y15816 & Y15824 \\
\hline Phytophthora cactorum & 39 & Fragaria & unknown & $\mathrm{Y} 15825^{\mathrm{c}}$ & $Y 15826^{c}$ \\
\hline Phytophthora cactorum & 55 & Fragaria & unknown & $\mathrm{Y} 15825^{\mathrm{c}}$ & $\mathrm{Y} 15826^{\mathrm{c}}$ \\
\hline Fusarium avenaceum & HPP 412 & R. arcticus & Alajärvi & Y15829 & Y15830 \\
\hline Phoma sp. & HPP $38^{d}$ & R. arcticus & unknown & Y15831 & Y15832 \\
\hline Botrytis cinerea & HPP 411 & R. arcticus & Himanka & Y15835 & Y15836 \\
\hline Cylindrocarpon destructans & HPP 410 & R. arcticus & Alajärvi & Y15833 & Y15834 \\
\hline
\end{tabular}

a Not determined.

b Isolates 62a1, 62a3, and 71 of $P$. sparsa had identical ITS1 sequences.

c No sequence difference was detected between the two Phytophthora cactorum isolates (provided by P. Parikka, Agricultural Research Centre, Finland).

d Isolated by Ruokola (19).

Table 3. Primers used for amplification of the complete ITS1 and ITS2 regions, detection of both Peronospora sparsa and Phytophthora cactorum, or specific detection of $P$. sparsa

\begin{tabular}{|c|c|c|}
\hline Primer name & Sequence & Specificity of amplification \\
\hline ITS1 (forward) & 5'-TCCGTAGGTGAACCTGCGG-3' & ITS1, universal ${ }^{\mathrm{a}}$ \\
\hline ITS2 (reverse) & 5'-GCTGCGTTCTTCATCGATGC-3' & ITS1, universal ${ }^{\mathrm{a}}$ \\
\hline ITS3 (forward) & $5^{\prime}$-GCATCGATGAAGAACGCAGC-3' & ITS2, universal ${ }^{\mathrm{a}}$ \\
\hline ITS4 (reverse) & 5'-TCCTCCGCTTATTGATATGC-3' & ITS2, universal ${ }^{\mathrm{a}}$ \\
\hline PR1 (forward) & 5'-CGAGCGTTTGGGCCTTGGCC-3' & P. sparsa and Phytophthora cactorum \\
\hline PR2 (reverse) & $5^{\prime}$-AATGGGTCGACCCTCGACAG-3' & P. sparsa and Phytophthora cactorum \\
\hline PR3 (forward) & 5'-GGCTGGCTGCTACTGGGCA-3' & P. sparsa \\
\hline PR4 (reverse) & $5^{\prime}$-GCCGACTGGCCACGCGGA-3' & P. sparsa \\
\hline
\end{tabular}

a Names and sequences of primers are according to White et al. (28). 
$\mathrm{MgCl}_{2}(1.5,2,3$, or $4 \mathrm{mM})$ concentrations, annealing temperature $\left(55\right.$ or $\left.60^{\circ} \mathrm{C}\right)$, extension time ( 3 min or 10 min with Mini Cycler; 0, 20, or $30 \mathrm{~s}$ with Rapid Cycler), number of cycles $(30,35$, or 40 cycles with Mini Cycler; 35, 40, or 45 cycles with Rapid Cycler). Additionally, the slope (increase/decrease of temperature) rates of 2, 3, or $4^{\circ} \mathrm{C} / \mathrm{s}$ were tested with Rapid $\mathrm{Cy}-$ cler. Two temperature-tolerant DNA polymerases ( $\mathrm{Taq}$ Polymerase II, IMB Fermentas; and Dynazyme TM II, Finnzymes OY) were tested with the Mini Cycler. Only Taq Polymerase II was tested with
Rapid Cycler, because Triton $\mathrm{X}-100$ is used with Dynazyme and is not suitable to be used in combination with bovine serum albumin (BSA) needed for amplification using the capillaries in Rapid Cycler (BSA is used in the capillaries to protect polymerase from denaturation) (30).

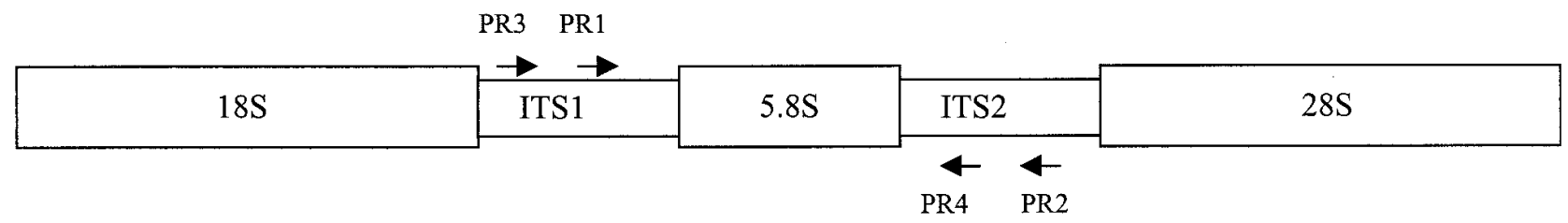

ITS1

Ps74 I CCACACCTAA AAAACTTTCC ACGTGAACCG TATCAACCAA CATAATTGGG GGT-TIGTTT GGTGGCGGCT GCTGGCATTT TGTGCTIGGCT GGCTGCTACT

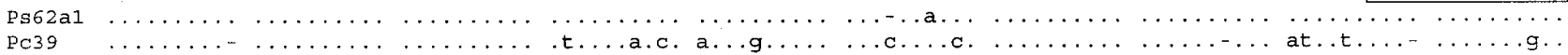

200

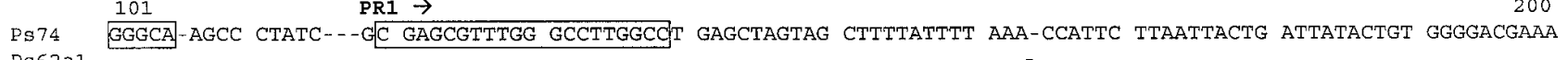

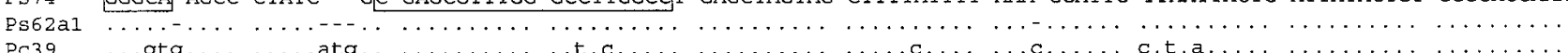

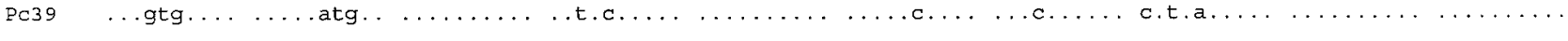

$\begin{array}{ll}201 & 223 \\ \text { Ps74 } & \text { GTCTCTGCTT TTAACTAGAT AGT }\end{array}$

Ps62a1 …...................

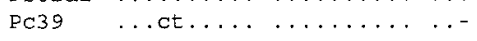

ITS2

1 . 100

Ps71 CATCAAACTT GGTTrTCTTC TTTCCGTGTA GTCGGTGGAG GATATGCCAG ATGTGAAGTG TCTTGCGGCT GATTTTCGGA TCGGCTGCGA GTCCTTTGAA

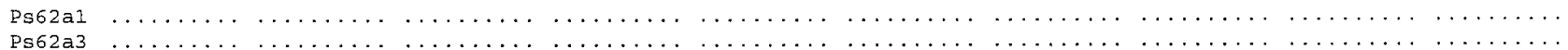

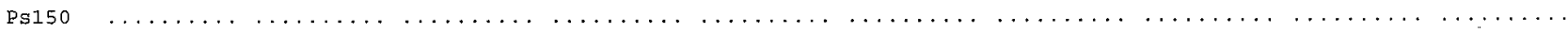

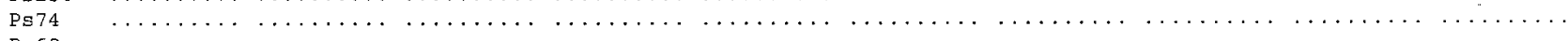

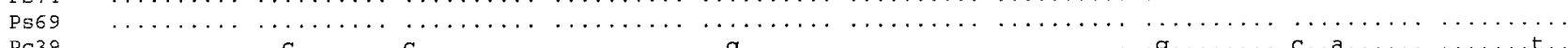

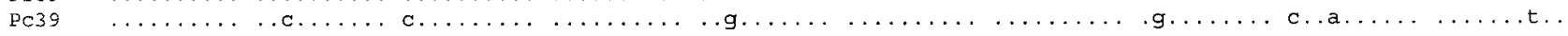

$101 \quad 200$

Ps71 ATGTACAGAA CTGTACTTCT CTITGCTCGA AAAGCATGGC GTTGCTGATT GTGGAGGCTG TCCGCGT--G GCCAGTCGGC GATCGGTTTG TCTGCTGTGG

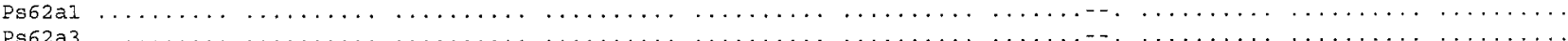

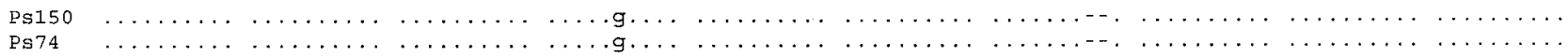

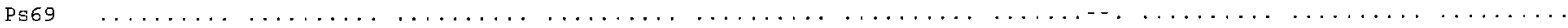

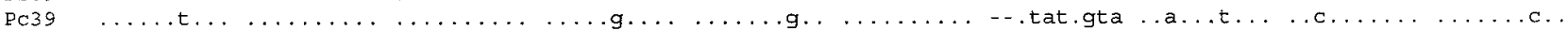

201

300

Ps71 C-TTAATGGA GGAGTGTTt ATTCGCGGTA TGATTGGCTT CGGCTGAAC- AGGCGCTTAT TGGACGTTCT TTCTGCTATG GCGGTATGGA CTGATGAACC

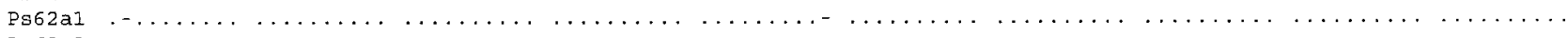

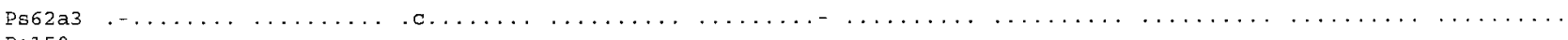

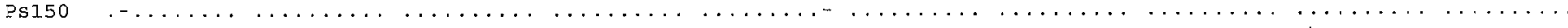

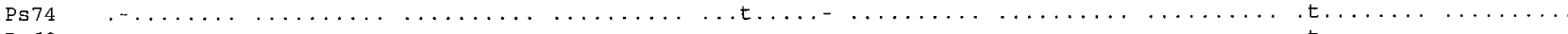

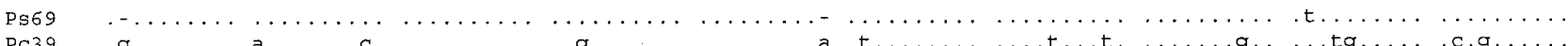

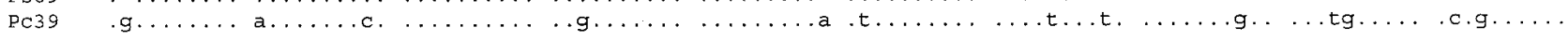

$301 \quad 400$

Es71 GTAGCTATGC GTTGACTTGG CITTTGAATT GGCTTTGCTG TTGCGAAGTA GAGTGGCAGT TTCAGCTGTC GAGGGTCGAC CCATTTGGGA AATTGTGCTG

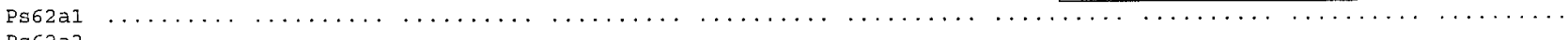

Ps62a3

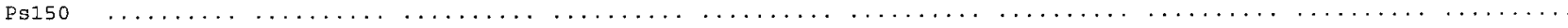

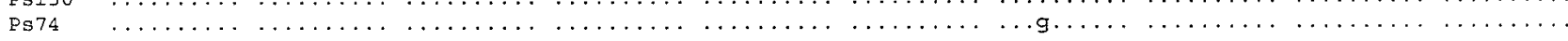

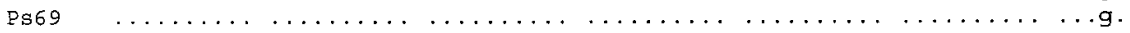

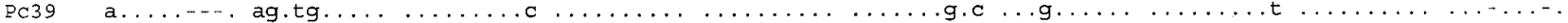

$\begin{array}{rlr}401 & 427 \\ \text { PS71 } & \text { TGCGGCTTCG GTCGTGTGGC ATCTCAA }\end{array}$

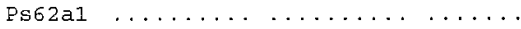

Ps62a3

Psis0 $\quad \cdots \cdots \cdots, \cdots \cdots \cdots \cdots$

Ps74 $\quad \cdots \cdots \cdots \cdots+\cdots \cdots \cdots$

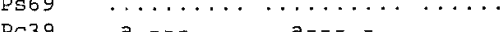

Fig. 4. Location of primers (PR1-PR4) designed for detection of Peronospora sparsa (isolates Ps71, Ps62a1, Ps62a3, Ps150, Ps74, and Ps69) and Phytophthora cactorum (isolates Pc39 and Pc55) in this study. ITS1 and ITS2 sequences were amplified with previously described universal primers targeted to the rDNA genes (28) and aligned using the Wisconsin Package Pileup program. ITS1 sequences of Ps62a1, Ps62a3, and Ps71 were identical, and only the sequence of Ps62a1 is shown. Similarly, no difference was detected in the ITS1 and ITS2 sequences of two isolates of $P$. cactorum, and only the sequences of isolate Pc39 are shown. 


\section{RESULTS}

Inspection of fungi in samples collected from the field. Fourteen of the 26 samples $(54 \%)$ collected from four cultivation sites in the beginning of August in 1995 (Table 1, Fig. 2) contained P. sparsa, but other fungi ( $F$. avenaceum, $C$. destructans and/or B. cinerea) also were detected in all plants. Rootstocks were collected from one cultivation where the dryberry disease had been very severe in the summer. Mycelia and sporangiophores of $P$. sparsa (Fig. 3) were observed on the top leaves of 16 plants $(59 \%)$ of the 27 plants examined after 4 to 5 weeks of growth at $17^{\circ} \mathrm{C}$. Three weeks later, $P$. sparsa was detected in two additional plants. At that time, $P$. sparsa formed sporangia on the flower stalks of three plants. After 12 weeks of growth, some of the other fungi (data not shown) mentioned were also detected in the leaves of the examined plants.

In 1996, cultivations of arctic bramble were inspected in western and eastern Finland in June and the beginning of July (Table 1, Fig. 2). In many cultivations, all plants had purple lesions in leaves, and sporangiophores of $P$. sparsa were visible on flower stalks (Fig. 1). Leaf samples were collected from plants on which sporangiophores were not seen, and inspected for fungi after incubation in the laboratory as described above. In several samples, $P$. sparsa was the only fungus observed (Table 1). Rootstocks were collected by farmers late in the autumn at a time when many night frosts or many days of freezing temperatures had killed the aboveground parts of the plants. Plants grown from these rootstocks were not monitored for more than 5 weeks, which was known to be enough for detection of $P$. sparsa but not necessarily sufficient for detection of other fungi. $P$. sparsa was detected in 32 plants $(29 \%)$ of the 110 plants examined (Table 1), but in many cases, it was not observed in all the shoots grown from a single rootstock.

Pathogenicity tests. Growth and formation of sporangia by $P$. sparsa on detached leaves inoculated with sporangia in the laboratory indicated that the fungus could readily infect arctic bramble. Inoculation of healthy, micropropagated plants of arctic bramble with suspensions of sporangia in the growth chamber also resulted in infection of all inoculated plants. Purple lesions often covered the whole leaf, and yellowing and poor growth were observed (Fig. 1). Sporulation was observed in a few leaves. However, plants did not flower, which was possibly associated with lack of flower induction due to previous propaga- tion in tissue culture. Therefore, the effects of $P$. sparsa on the development of berries could not be examined.

ITS sequences and primer design for PCR-based detection of fungi. ITS1 and ITS2 sequences were determined in four and six isolates, respectively, of $P$. sparsa obtained from the rootstocks examined in 1996 (Table 2, Fig. 4). ITS1 sequences (117 nt) were identical except for one nucleotide position in isolate Ps74 (Fig. 4). Also, ITS2 sequences (423 nt) were very similar among the six isolates analyzed. Differences were found in five nucleotide positions (Fig. 4). ITS1 and ITS2 sequences of $R$. arcticus cv. Pima (EMBL accession no. Y15827 and Y15828, respectively) and of one isolate each of $F$. avenaceum, $C$. destructans, Phoma sp., and $B$. cinerea obtained from arctic bramble were also determined (Table 2) and compared with the corresponding sequences of $P$. sparsa (not shown). Subsequently, primers PR1 and PR2 were designed (Table 3, Fig. 4). These primers amplified a product of $0.64 \mathrm{~kb}$ only from $P$. sparsa and arctic bramble infected with $P$. sparsa but not from healthy arctic bramble or the fungi mentioned above (Fig. 5) under the reaction conditions optimized for the two thermal cyclers (Table 4).
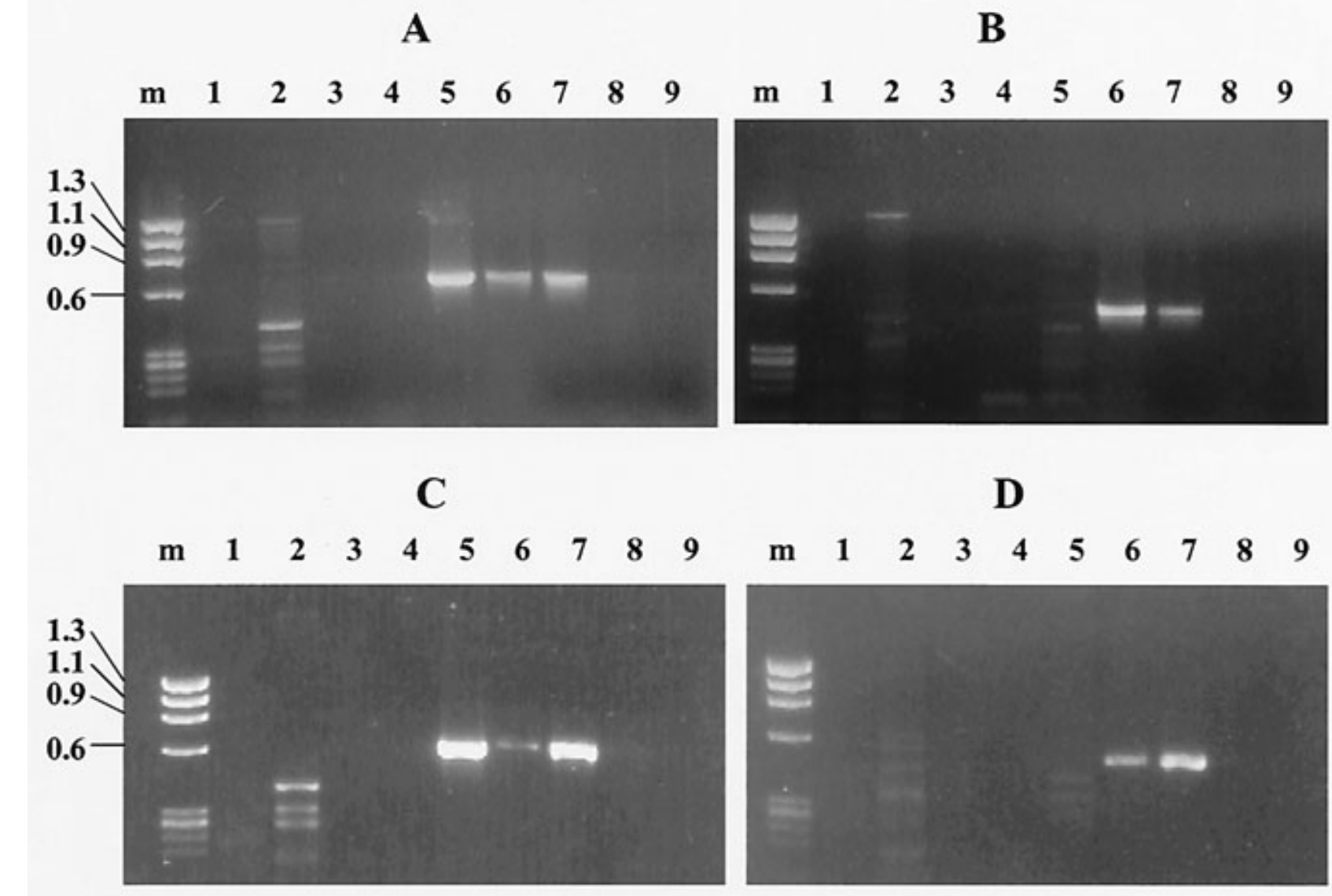

Fig. 5. Detection of Peronospora sparsa and Phytophthora cactorum with the primer pair PR1/PR2 (A and C), and specific detection of $P$. sparsa with the primer pair PR3/PR4 (B and D) using the Mini Cycler (A and B) and Rapid Cycler (C and D) polymerase chain reaction (PCR) machines. Primer sequences and reaction conditions are indicated in Tables 3 and 4, respectively. Lane m, DNA marker (marker sizes are indicated in kilobases); lane 1, Phoma sp.; lane 2, Cylindrocarpon destructans; lane 3, Botrytis cinerea; lane 4, Fusarium avenaceum; lane 5, Phytophthora cactorum; lane 6, P. sparsa; lane 7, arctic bramble infected with $P$. sparsa; lane 8, healthy arctic bramble; lane 9, reaction mix without template (negative control). 
Phytophthora cactorum is not reported to occur in arctic bramble. However, arctic bramble is often grown on farms specialized to berry production, including strawberries, which can be infected with Phytophthora cactorum $(14,16)$. Therefore, it was presumed that samples of arctic bramble could contain Phytophthora cactorum in some cases, which should be taken into account while developing a test for specific detection of $P$. sparsa. Two isolates of $P$. cactorum were tested by amplification with primers PR1 and PR2, and a product of size similar to $P$. sparsa was obtained (Fig. 5). ITS1 and ITS2 sequences of the two Phytophthora cactorum isolates were determined, and no nucleotide difference was found, but comparisons to the corresponding sequences of $P$. sparsa revealed many nucleotide differences (Fig. 4). Subse-

Table 4. Optimized conditions for the use of the primer pairs PR1/PR2 and PR3/PR4, in Mini Cycler (PTC150, MJ Research) and Rapid Cycler (Idaho Technology) polymerase chain reaction (PCR) machines

\begin{tabular}{lll}
\hline & Mini Cycler & Rapid Cycler \\
\hline Reaction mix & & \\
dNTPs & $0.1 \mathrm{mM}$ & $0.2 \mathrm{mM}$ \\
Primer 1 (forward) & $0.25 \mu \mathrm{M}$ & $0.5 \mu \mathrm{M}$ \\
Primer 2 (reverse) & $0.25 \mu \mathrm{M}$ & $0.5 \mu \mathrm{M}$ \\
$\mathrm{MgCl}_{2}$ & $1.5 \mathrm{mM}$ & $4.0 \mathrm{mM}$ \\
Bovine serum albumin & $\mathrm{Not}$ added & $250 \mu \mathrm{g} / \mathrm{ml}$ \\
DNA polymerase & $1.0 \mathrm{U}$ & $0.8 \mathrm{U}$ \\
Total volume & $50 \mu \mathrm{l}$ & $15 \mu \mathrm{l}$ \\
Reaction cycles & & \\
Step 1 at $94^{\circ} \mathrm{C}$ & $1 \mathrm{~min}$ & $15 \mathrm{~s}$ \\
Step 2 at $94^{\circ} \mathrm{C}$ & $45 \mathrm{~s}$ & $\mathrm{NS}$ \\
Step 3 at $60^{\circ} \mathrm{C}$ & $45 \mathrm{~s}$ & $\mathrm{NS}$ \\
Step 4 at $72^{\circ} \mathrm{C}$ & $45 \mathrm{~s}$ & $20 \mathrm{~s}$ \\
Steps 2 to 4 repeated & 35 times & 45 times, slope $2.0^{\circ}$ \\
Step 5 & $3 \mathrm{~min}$ at $72^{\circ} \mathrm{C}$, then cool to $4^{\circ} \mathrm{C}$ & Cool to room temperature (or $4^{\circ} \mathrm{C}$ ) \\
\hline
\end{tabular}

${ }^{\mathrm{a}}$ Heat tolerant Taq DNA Polymerase II (IMB Fermentas) and Dynazyme TM II DNA polymerase (Finnzymes) worked equally well in Mini Cycler, but only Dynazyme TM II was tested using Rapid Cycler. Polymerases were used with the corresponding $10 \times$ PCR buffer and $\mathrm{MgCl}_{2}$ solution provided by the enzyme manufacturer.

${ }^{b}$ Filled to total volume with sterile distilled water. PCR with Mini Cycler was carried out in 0.5-ml microfuge tubes; whereas reactions with Rapid Cycler were carried out in glass capillars (Idaho Technology).

${ }^{\mathrm{c}}$ Nonstop; slope 2.0, i.e., during each cycle, temperature was gradually decreased from 94 to $60^{\circ} \mathrm{C}$, then increased to $72^{\circ} \mathrm{C}$, and after $20 \mathrm{~s}$ increased to $94^{\circ} \mathrm{C}$ at the speed of $2^{\circ}$ per s.

quently, a new pair of primers (PR3 and PR4) was designed (Table 3, Fig. 4). With these primers, a product of $0.56 \mathrm{~kb}$ was amplified only from $P$. sparsa and arctic bramble infected with $P$. sparsa (Fig. 5) under the reaction conditions optimized for the two thermal cyclers (Table 4).

Detection limit of the test was examined using a template prepared by mixing different amounts of $P$. sparsa total DNA with $3 \mathrm{ng}$ of total DNA extracted from leaves of healthy arctic bramble. As little as $0.25 \mathrm{pg}$ of $P$. sparsa DNA resulted in amplification of a product of expected size, detectable in an agarose gel stained with ethidium bromide, with both primer pairs (PR1/PR2 and PR3/PR4) and thermal cyclers (Fig. 6).

\section{DISCUSSION}

This study showed that $P$. sparsa is widespread and common in cultivated arctic bramble in Finland and occurs in cultivations over the whole main production area (Fig. 2). Our data do not prove that $P$. sparsa is the only causal agent of the sudden, severe disease epidemics encountered on arctic bramble and causing large yield losses since 1994 in Finland, but this possibility is not excluded. Other fungi, such as $F$. avenaceum, $C$. destructans, and $B$. cinerea, that were also detected in this study-but not $P$. sparsawere reported to be relatively common in arctic bramble already in the 1970 s (19). However, no significant yield losses were reported until the 1990s. Thus, yield losses

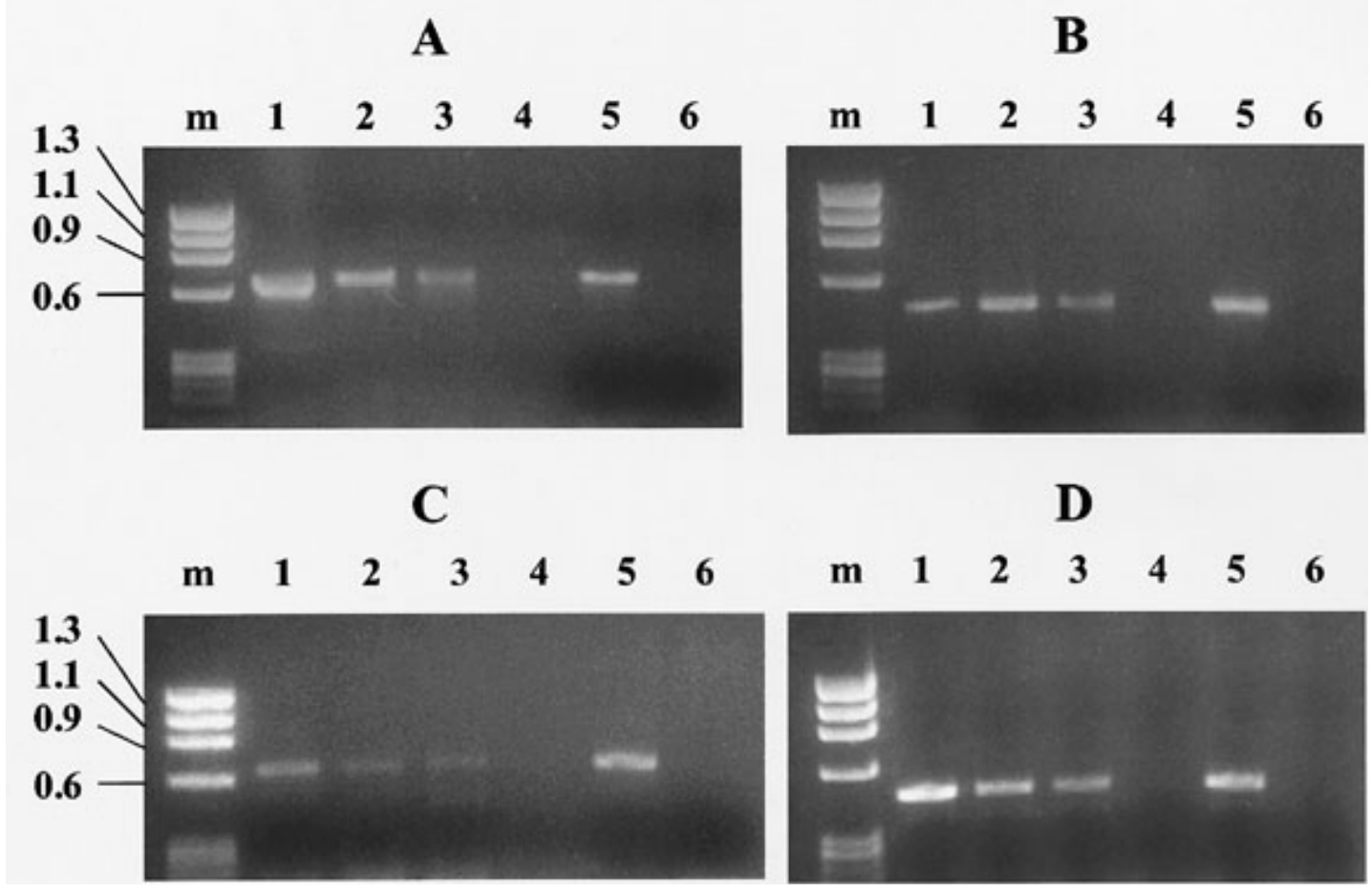

Fig. 6. Sensitivity of detection of Peronospora sparsa with the primer pairs PR1/PR2 (A and C), and PR3/PR4 (B and D) using the Mini Cycler (A and B) and Rapid Cycler (C and D) polymerase chain reaction (PCR) machines. Primer sequences and reaction conditions are indicated in Tables 3 and 4 , respectively. In the reactions analyzed in lanes 1 to 3 , the indicated amount of $P$. sparsa DNA was mixed with $3 \mathrm{ng}$ of total DNA extracted from healthy arctic bramble. Lane m, DNA marker (marker sizes are indicated in kilobases); lane 1, $0.01 \mathrm{ng}$; lane 2, $0.001 \mathrm{ng}$; lane 3, $0.00025 \mathrm{ng}$; lane 4, healthy arctic bramble (3 ng); lane 5, P. sparsa (0.01 ng); lane 6, reaction mix without template (negative control). 
seem to coincide with the appearance of $P$. sparsa.

Cultivation of arctic bramble is largely based on two selected clones, cvs. Pima and Mespi, that are vegetatively propagated. Inoculation of detached leaves of cv. Pima with sporangia of $P$. sparsa in the laboratory and the consequent rapid growth of the fungus and formation of sporangia showed that Pima was quite susceptible to $P$. sparsa. Inoculation of whole plants of cvs. Pima and Mespi in a growth chamber demonstrated formation of red lesions in leaves and significant reduction of growth following infection, although the experiments failed to prove or disprove any role of $P$. sparsa as the cause of the "dryberry" symptoms observed in the field. Thus, both main cultivars of arctic bramble seem to be susceptible to $P$. sparsa.

The growing seasons 1994 to 1996 were characterized by several weeks of cool and rainy weather in June. In 1995, samples were collected late in the growing season in August after several weeks of hot and sunny weather. However, P. sparsa was detected in these samples, and inspection of cultivations was done earlier in 1996 during the cool and rainy period in June and early July. At this time, sporangiophores and sporangia of $P$. sparsa could be readily seen on many plants, and most or all plants in a cultivation had distinct purple lesions on the leaves. These observations suggested that the growth of $P$. sparsa was favored by cool and moist conditions, as previously reported on other plant species $(1,8)$; symptoms were best distinguished in young plants at start of flowering; and most if not all plants in a cultivation were infected.

All samples in 1995 and the leaf samples in 1996 were collected by an experienced mycologist. In 1996, almost all (88\%) collected leaf samples were infected with $P$. sparsa according to analyses in the laboratory. However, the rootstocks were collected in 1996 by farmers after night frosts and/or daily freezing temperatures had killed the aboveground parts of the plants. Therefore, they represented a random sample of plants from cultivation sites where the disease had been severe in the summer. Interestingly, $P$. sparsa was detected only in $29 \%$ of these rootstocks. While our data indicated that $P$. sparsa can be retained in belowground parts of infected plants and grow systemically to new shoots in the next growing season, the data also suggested that this was probably not the case in all infected plants. Reasons for this phenomenon remain to be studied. Furthermore, these data and the observation that in many cultivations almost all plants had foliar symptoms characteristic of infection with $P$. sparsa suggested that dispersal of sporangia may play a role in the spread of the disease during the growing season.

$P$. sparsa is an obligate parasite (7) and cannot be grown on artificial growth me- dia. Hence, its detection in plant samples is complicated, as it cannot be grown from plant tissues to culture media for identification. Also, other fungi in the same sample can interfere with detection of $P$. sparsa. Therefore, a rapid PCR-based detection method was developed for identification of $P$. sparsa directly from total DNA extracts of infected plants. The ITS regions between the conserved rDNA genes evolve faster and possess interspecific variation $(11,28)$. Thus, they are useful for PCRbased identification and detection of fungi, as reported on, e.g., Verticillium (13), Fusarium (15), Gaeumannomyces (5), Colletotrichum (22), and Phytophthora (26). Determination and comparison of the ITS sequences of several isolates of $P$. sparsa in this study indicated few nucleotide differences; whereas the ITS sequences in other fungi isolated from arctic bramble and the ITS sequences of arctic bramble were quite different from the corresponding sequences of $P$. sparsa. Thus, primers targeted to the ITS regions could be designed for specific detection of $P$. sparsa. The method used for DNA extraction resulted in DNA preparations with a good suitability as templates for PCR amplification, and as little as $0.25 \mathrm{pg}$ of $P$. sparsa DNA could be detected in a reaction mix containing $3 \mathrm{ng}$ of total DNA of arctic bramble.

The rapid outbreak of $P$ sparsa in cultivated arctic bramble in Finland seems to be attributable to cultivation of two susceptible clones, perennial growth of arctic bramble, ability of $P$. sparsa to overwinter in the rootstocks, quick increase of the total cultivation area in the 1990s, and cool and rainy weather in the early summer during three consecutive years. However, it is unknown whether the cultivated arctic bramble is the only source of infection in Finland or whether other Rubus spp. (8) or Rosa spp. (1) retain $P$. sparsa. This question can be effectively addressed in the future by screening large numbers of samples collected from the field using the PCR test developed in this study. $P$. sparsa can remain symptomless in in vitro propagated clones of other Rubus spp. (27), and therefore the PCR test developed in this study will also be used for indexing cuttings and micropropagated arctic bramble for the absence of $P$. sparsa prior to distribution to farmers.

\section{ACKNOWLEDGMENTS}

We thank S. Pirttikoski, M. Uosukainen, E. Teperi, and D. J. Jacobson (Michigan State University) for fruitful discussions and project planning, several farmers for providing samples, P. Parikka for the isolates of Phytophthora cactorum, J. Hantula and R. Kasanen for the DNA isolation method, and J. F. Kreuze and S. Gunnarsson for help in preparation of figures. Financial support from Merenkurkun Neuvosto and the Finnish Ministry of Agriculture and Forestry (grant 762/507/97) is gratefully acknowledged.

\section{LITERATURE CITED}

1. Breese, W. A., Schattock, R. C., Williamson, B., and Hackett, C. 1994. In vitro spore ger- mination and infection of cultivars of Rubus and Rosa by downy mildews from both hosts. Ann. Appl. Biol. 125:73-85.

2. Domsch, K. H., Gams, W., and Anderson, T.H. 1980. Compendium of Soil Fungi. Vol. 1 and 2. Academic Press, London.

3. Ellis, M. B. 1971. More Dematiaceous Hyphomycetes. C.A.B. International, Kew, Eng.

4. Francis, S. M., and Waterhouse, G. M. 1988. List of Peronosporaceae reported from the British Isles. Trans. Br. Mycol. Soc. 91:1-62.

5. Goodwin, P. H., Hsiang, T., Xue, B. G., and Liu, H. W. 1995. Differentiation of Gaeumannomyces graminis from other turf-grass fungi by amplification with primers from ribosomal internal transcribed spacers. Plant Pathol. 44:384-391.

6. Graham, J., McNicol, R. J., and McNicol, J. W. 1996. A comparison of methods for the estimation of genetic diversity in strawberry cultivars. Theor. Appl. Genet. 93:402-406.

7. Hall, G. 1989. Peronospora rubi. CMI Descriptions of Pathogenic Fungi and Bacteria No. 976. Mycopathology 106:195-197.

8. Hall, H. K., and Shaw, C. G. 1987. Brambles: Downy mildew on wild and cultivated Rubus species in New Zealand. N.Z. J. Exp. Agric. 15:57-60.

9. Higgins, D. G., Bleasby, A. J., and Fuch, R. 1992. CLUSTAL V: Improved software for multiple sequence alignment. Computer Appl. Biosci. (CABIOS) 8:189-191.

10. Hultén, E. 1971. The circumpolar plants II. Dicotyledons. Kungl. Sv. Vet. Akad. Handl. 4 Ser. 13, 1:164-165, 373-375.

11. Lee, S. B., and Taylor, J. W. 1992. Phylogeny of five fungus-like protoctistan Phytophthora species, inferred from the internal transcribed spacers of ribosomal DNA. Mol. Biol. Evol. 9(4):636-653

12. McKeown, B. 1988. Downy mildew of boysenberry and tummelberry in the UK. Plant Pathol. 37:281-284.

13. Nazar, R. N., Hu, X., Schmidt, J., Culham, D. and Robb, J. 1991. Potential use of PCR-amplified ribosomal intergenic sequences in the detection and differentiation of Verticillium wilt pathogens. Physiol. Mol. Plant Pathol. 39:1-11.

14. Nienhaus, F. 1960. Das Wirtsspectrum von Phytophthora cactorum (Leb. Et Cohn) Schroet. Phytopathol. Z. 38:33-68.

15. O'Donnell, K. 1992. Ribosomal DNA internal transcribed spacers are highly divergent in the phytopathogenic ascomycete Fusarium sambucinum (Gibberella pulicaris). Curr. Genet. 22:213-220.

16. Parikka, P. 1991. Phytophthora cactorum on strawberry in Finland. Nord. Jordbrugsforsk. 73:121.

17. Porebski, S., Grant, L., and Baum, B. R. 1997. Modification of a CTAB DNA extraction protocol for plants containing high polysaccharide and polyphenol components. Plant Mol. Biol. Rep. 15:8-15.

18. Ridell J., Siitonen, A., Paulin, L., Lindroos, O., Korkeala, H., and Albert, M. J. 1995 Characterization of Hafnia alvei with biochemical tests, RAPD-PCR and partial sequencing of the $16 \mathrm{~S}$ rRNA gene. J. Clin. Microbiol. 33:2372-2376.

19. Ruokola, A.-L. 1981. Fungus disease of cultivated arctic bramble (Rubus arcticus L.) in Finland. J. Sci. Agric. Soc. Finl. 53:83-89.

20. Ryynänen, A. 1973. Rubus arcticus and its cultivation. Ann. Agric. Fenn. 12:1-76.

21. Ryynänen, A., and Dalman, P. 1983. A new variety of arctic bramble 'Pima'. Ann. Agric. Fenn. 22:1-7.

22. Sreenivasaprasad, S., Sharada, K., Brown, A. E., and Mills, P. R. 1996. PCR-based detection of Colletotrichum acutatum on strawberry. Plant Pathol. 45:650-655.

23. Tate, K. G. 1979. Crown and root infection of 
boysenberry plants by the downy mildew (dryberry) fungus. Comm. Hortic. 8:23-25.

24. Tate, K. G. 1981. Aetiology of dryberry disease of boysenberry in New Zealand. N.Z. J. Exp. Agric. 9:371-376.

25. Thompson, J. D., Higgins, D. G., and Gibson, T. J. 1994. CLUSTAL W: Improving the sensitivity of progressive multiple sequence alignment through sequence weighting, position specific gap penalties and weight matrix choice. Nucleic Acids Res. 22:4673-4680.
26. Tooley, P. W., Bunyard, B. A., Carras, M. M., and Hatziloukas, E. 1997. Development of PCR primers from internal transcribed spacer region 2 for detection of Phytophthora species infecting potatoes. Appl. Environ. Microbiol. 63:1467-1475.

27. Wallis, W. A., and Shattock, R. C. 1989. Downy mildew (Peronospora rubi) on micropropagated Rubus. Acta Hortic. 262:227-230.

28. White, T. J., Burns, T., Lee, S., and Taylor, J. 1990. Amplification and direct sequencing of fungal ribosomal RNA genes for phylogenetics. Pages 315-322 in: PCR Protocols: A Guide to Methods and Applications. M. A. Innis, D. H. Gelfand, J. J. Sninsky, and T. J. White, eds. Academic Press, San Diego, CA.

29. Wittwer, C. 1994. Rapid cycle DNA amplification-the 10 most common mistakes. The Rapid Cyclist 1:11-12.

30. Wittwer, C. T., and Garling, D. J. 1991. Rapid cycle DNA amplification: Time and temperature optimization. Bio/Technology 10:76-83. 